\title{
CORRECTION
}

\section{Litigious future for Big Sugar?}

The News article entitled "Litigious future for Big Sugar?” published on Mar. 6, 2017, contained an error in a date. It should have stated, "This is a 2014 number, and is a $20 \%$ reduction from 2004," said Carolyn Fell, a senior communications direction with the association, citing a Conference Board of Canada report.

CMAJ apologizes for the error and any inconvenience it may have caused.

n Cite as: CMAJ 2017 April 24;189:E614. doi: 10.1503/cmaj.170403

\section{Reference}

1. Collier R. Litigious future for Big Sugar? CMAJ 2017;189:E378-9. 